\title{
A NOTE ON THE BACTERIOLOGICAL EXAMINATION OF MILK.*
}

\author{
BY GEORGE NEWMAN, M.D., D.P.H., F.R.S.E. \\ Medical Officer of Health of the Metropolitan Borough of Finsbury; \\ Joint Author of "The Bacteriology of Milk."
}

The importance of, and need for, a safe minimum of bacteriological examination and a broad standard as to purity of milk.

A minimum bacteriological examination of milk should include :-

1. The number of bacteria per cubic centimetre. This is of relative importance only, it has little if any absolute value, as, of itself, it affords no safe guidance as to quality. It has recently been suggested in England that a suitable standard can be laid down, namely, 100,000 organisms per cc., but this, as every milk bacteriologist knows, is altogether impracticable. The Philadelphia Milk Commission laid down a standard of 10,000 bacteria per cc., and no pus cells or injurious germs. The New York Milk Commission set the figure at 30,000. Both standards are impracticable from a bacteriological point of view and from an hygienic. Such estimations are valueless unless carried out on precisely identical conditions as to media, incubation, temperature, time of counting, method of counting, etc. Moreover, good, fresh milks often contain many thousands of organisms per ce.

Numerical estimation only of scientific value when $(a)$ making a series of comparative examinations under precisely similar conditions of the same milk supply, and $(b)$ making examinations after filtration of milk, or pasteurization, sterilization, etc. Leighton, of Montclair, U.S.A., has shown the utility of comparative series, and that the number of colonies growing on media bears a direct relation to clean or unclean dairying.

2. The kinds of bacteria and toxins present in milk. Methods of determination discussed. Classification of species:-

(a) Lactic organisms-forming, as a rule, from 60 to 90 per cent of all bacteria present in milk.

(b) Organisms indicative of contamination, e.g., B. coli communis, $B$. enteritidis sporogenes, $B$. enteritidis of Gaertner, streptococcus, and organisms of dust, soil, and manure-a number of the latter being acid-fast.

* Outline of a Paper read at King's College, on July 20th, 1905, at the Congress of the Royal Institute of Public Health. The Editor much regrets that the complete paper was wholly destroyed in a serious fire which occurred at the printers of PeBric Health. 
Methods of isolation and proportionate presence of these organisms discussed. The presence and pathogenicity of streptococcus discussed. The mere presence of organisms having morphology of streptococcus insufficient, as such are found frequently in good milk. But virulent streptococcus may occur in milk drawn from inflamed udders (mammitis). Bergey's work on streptococcus in market milk, Gordon's work on streptococeus in human saliva. The relationship of the organism in saliva, soil, etc., to milk. Importance of testing virulence.

Delépine's work on the bacillus enteritidis of Gaertner; animal inoculation the only reliable test. The virulence of milk containing this organism. Probable source of organism, the intestine of the cow. Klein's examination of milk in City of London, 1904, and the relative presence of organisms of indication discussed.

(c) Pathogenic organisms, such as $B$. enteritidis of Gaertner, $B$. diphtherice, B. tuberculosis, and B. typhosus.

Methods of determination and the frequency of their presence.

3. The presence or absence of organic cells foreign to clean milk (pus, blood, yeast) and the quantity and nature of general dirt and particulate matter other than milk constituents.

The Woking, Bedford, and other outbreaks in which pus cells were found. The Lincoln yeast (Klein).

4. The degree of Acidity. Particular attention was drawn to this test as the most ready and rapid, and on the whole, the most reliable general test as to the staleness or otherwise of a milk.

Method of determination : $100 \mathrm{cc} .+2 \mathrm{cc}$. of a 0.1 per cent solution of phenol-phthalein and subsequent titration with a deci-normal solution of caustic soda until faint pink colour begins to become permanent. Generally some $15-20 \mathrm{cc}$. of $\frac{x}{10}$ alkali necessary. Each cc. of $\frac{\mathrm{y}}{10}$ solution is termed "one degree of total acidity," and is equal to about 0.009 grams of lactic acid. Important point, total acidity, which shall not exceed 24-25 degrees.

Value of the test discussed. Chemical analysts might at once carry out such examination and enter results in certificates along with fat and solids not fat. No new machinery needed to obtain results.

A suggested Bacteriological Standard of purity of milk for practical purposes :-

(a) Not more than $24-25$ degrees of total acidity.

(b) Not an excess of pus or blood cells.

(c) Not any $B$. coli, $B$. enteritidis sporogenes, or $B$. enteritidis of Gaertner in one cc. 
(d) The milk to be non-virulent. Test of virulence in animals not always fair criterion of actual danger to man, but a prima facie case against the milk.

$(a)$ and $(d)$ to be fixed and absolute standards upon which, when necessary, action shall be taken against the vendor of the milk. The case of Roberts v. St. Pancras Borough Council was cited; judgment at Tower Bridge Police Court, May 12th, 1905; milk proved to be virulent by animal inoculation.* The taking of action on high degrees of acidity not less reasonable than taking action on fat percentages, and of more value as an indication of unsatisfactory quality of milk.

$(b)$ and $(c)$ to be relative standards necessitating not legal proceedings but further enquiry into the health of the cow, and the efficiency and cleanliness of the whole dairying process, including the milk-shop treatment, and the contractor's "manipulation." If topographical findings rather than bacteriological are more reliable in respect of oysters, the same is still more the case in respect of milk. Milk should be judged broadly by topographical facts as well as chemical and bacteriological. Excess of pus or blood cells, or the presence of organisms of contamination in $1 \mathrm{cc}$. should indicate further enquiry in all cases.

Medical Inspector under the Alifns Act at the Port of Hull.Representatives of the Hull and Goole Port Sanitary Authority have had a conference with the Departmental Committee, with reference to the appointment for the port of Hull of a Medical Inspector under the Act. The Act requires the Home Secretary to appoint a Medical Officer at such ports as he thinks necessary, and the Committee stated that as there would have to be a medical inspection of immigrants at the Port of Hull, they were desirous of making an arrangement whereby the Medical Officer of the Port Sanitary Authority could be appointed Medical Inspector under the Act, so as to avoid the necessity of having the immigrants examined by two different medical men. They suggested that as the Medical Officer of the Port Sanitary Authority would probably not be able to do the work personally, it should be done under his supervision by an assistant, whose salary should be paid by the Port Sanitary Authority and recouped by the Government. They stated they preferred not to appoint an independent officer, but one who was engaged in public health work, and would be responsible to the Authorities, and they asked that a proposal might be submitted to them through the secretary for the work being undertaken, as suggested by the Medical Officer of the Port Sanitary Authority, as a provisional arrangement for twelve months from the 1st January next, to see how it worked. It was estimated that the work would probably entail an inspection of from twelve to fifteen vessels a week, and they trusted to have the hearty co-operation of the Sanitary Authorities in the work, which would be for the benefit of the port.

* Reported Public Health, vol. xvii, p. 617. 